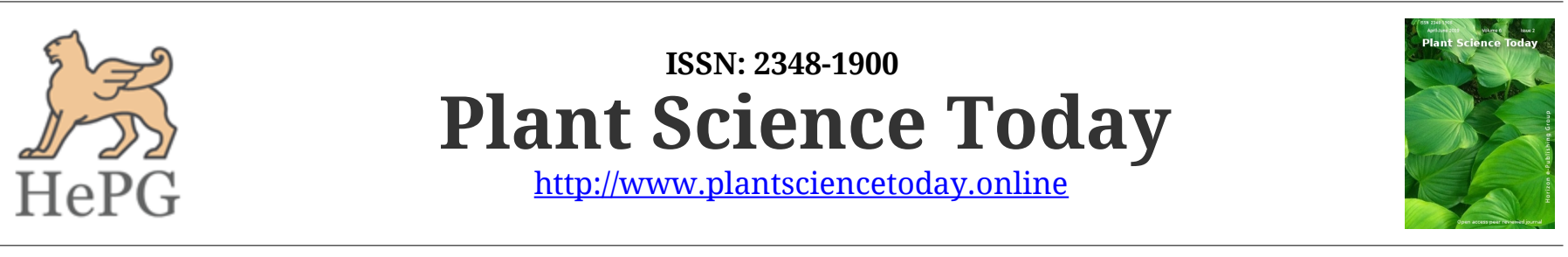

OPEN ACCESS

Review Article

\title{
Phytotherapy: An anti-hepatotoxicity and hepatoprotective approach in chemotherapy
}

\author{
Koroush Ghanadi ${ }^{1,2}$, Afshin Hasanvand ${ }^{3}$, Saber Abbaszadeh ${ }^{3,4}$, Saeid Heidari-Soureshjani ${ }^{{ }^{*}}$, Tahra \\ Suhan $^{6}$
}

${ }^{1}$ Hepatitis Research Center, Lorestan University of Medical Sciences, Khorramabad, Iran

${ }^{2}$ Digestive Disease Research Center, Tehran University of Medical Sciences, Tehran, Iran

${ }^{3}$ Student Research Committee Lorestan University of Medical Sciences, Khorramabad, Iran

${ }^{4}$ Razi Herbal Medicines Research Center, Lorestan University of Medical Sciences, Khorramabad, Iran

${ }^{5}$ Medical Plants Research Center, Basic Health Sciences Institute, Shahrekord University of Medical Sciences, Shahrekord, Iran

${ }^{6}$ Department of Pediatrics-Hematology/Oncology, Ann Arbor, MI, USA

\section{Article history}

Received: 25 February 2019

Accepted: 10 March 2019

Published: 01 April 2019

\section{Editor}

Dr. K. K. Sabu

Jawaharlal Nehru Tropical Botanic Garden and Research Institute

Thiruvananthapuram, India

\section{Publisher}

Horizon e-Publishing Group

\author{
*Correspondence \\ Saeid Heidari-Soureshjani \\ $凶$ heidari 1983@yahoo.com
}

\begin{abstract}
Chemotherapy induced-hepatotoxicity is one of the prevalent problems among cancer patients, with a wide spectrum of complications from liver dysfunction to liver necrosis. Therefore, in this study, we review the research findings on the effects of medicinal herbs and herbal compounds on the hepatotoxicity induced by anticancer drugs. The words hepatotoxicity and hepatoprotective along with the words cancer drug or chemotherapy in combination with some herbal terms such as medicinal plant, phyto* and herb* were used to search for relevant publications indexed in the Institute for Scientific Information (ISI) and PubMed. Available evidence shows that certain medicinal plants and herbal derivatives can reduce cancer drug-induced hepatotoxicity and protect liver cells against complications by regulating hepatic enzymes and increasing antioxidant enzyme activities. Some herbal formulations, including traditional Chinese medicine, have also been reported to exhibit such effects. Medicinal plants can exert anti-hepatotoxicity effects mainly by increasing antioxidant activity, inhibiting inflammatory processes, and reducing cell necrosis induced by anti-cancer drugs. Phytotherapy can be used as an effective complementary treatment for anticancer drug-induced hepatotoxicity and prevent various complications in the liver.
\end{abstract}

Keywords: Hepatotoxicity; Hepatoprotective; Medicinal herbs; Cancer drugs; Chemotherapy

Citation: Ghanadi K, Hasanvand A, Abbaszadeh S, Heidari-Soureshjani S, Suhan T. Phytotherapy: An anti-hepatotoxicity and hepatoprotective approach in chemotherapy. Plant Science Today 2019;6(2):114-122. https://doi.org/10.14719/pst.2019.6.2.514

Copyright: (c) Ghanadi et al (2019). This is an open-access article distributed under the terms of the Creative Commons Attribution License, which permits unrestricted use, distribution, and reproduction in any medium, provided the original author and source are credited (https://creativecommons.org/licenses/by/4.0/).

Indexing: Plant Science Today is covered by Scopus, CAS, AGRIS, CABI, Google Scholar, etc. Full list at http://www.plantsciencetoday.online

\section{Introduction}

With the spread of industrialization, cancers are one of the major causes of death in the world, with approximately 14 million new cases and 8.2 million cancer-associated deaths in 2012 (1). Anticancer drugs may cause hepatotoxicity alone or due to interaction with other drugs, which is transient in some cases, or leads to liver tissue damage and threatens the life of the individual in other cases 
$(2,3)$. Certain classes of chemotherapeutic agents such as alkylating agents, anti-metabolites, antitumor antibiotics, isomerase inhibitors and mitotic inhibitors, hormone therapy and immunotherapy cause hepatotoxicity (2). Sinusoidal obstructive syndrome (SOS), steatosis, pseudocirrhosis, acute hepatitis and necrosis are conditions that correlate with liver abnormalities in patients being treated with chemotherapy and lead to abnormal liver test results $(4,5)$. However, the hepatotoxicity mechanism is still unclear (5). Although the use of hepatoprotective agents in oncology is beneficial, no documented evidence exists for their clinical use (6). Traditional and complementary medicine (TCM) approaches (Such as aromatherapy, hypnotherapy, yoga, massage therapy, use of medicinal plants, etc.) have been used to prevention and treatment diseases (7-13), where the herbal-based medicines were the most commonly used form of TCM (14-20). They have little to no side effects compared with synthesis drugs. Various studies have shown that medicinal herbs can be effective, inexpensive, and efficient treatments for various diseases, including against toxicity (21-30). Hepatoprotective agents seem to be useful in the oncologic setting, yet they are still not widely documented for clinical usage (6). Therefore, this article reviews research findings on the effects of medicinal plants and plant compounds on anticancer drug-induced hepatotoxicity.

\section{Search strategies}

The key words of interest and Endnote software were used to conduct this review. The key words hepatotoxicity and hepatoprotective along with the words cancer drug or chemotherapy in combination with some herbal terms such as medicinal plant, phyto*, and herb* were used to search for relevant publications indexed in the Institute for Scientific Information (ISI) and PubMed with EndNote software (Table 1).

A standard form was designed, which included items such as aim or the title of the study, intervention, outcome, variables, journal name, period, and number. The article's contents that were relevant to this study were recorded on the form and entered into the study upon agreement of the researchers involved in this study. Then the plants and the plant-based products that were reported to be effective to treat or reduce symptoms of cancer drug-induced hepatotoxicity were selected. The articles whose full texts were not accessible, studies with non-positive effects, non-English language articles, review articles, and studies that were not related to the purpose of this study were excluded after all researchers in this study agreement was achieved. Fig. 1 illustrates how the articles were selected for final analysis.
Table 1: Number of studies divided by database

\begin{tabular}{|c|c|c|}
\hline \multirow{2}{*}{$\begin{array}{l}\text { Hepatotoxicity+ cancer drug+ medicinal } \\
\text { plant }\end{array}$} & PubMed & 14 \\
\hline & ISI & 17 \\
\hline \multirow{2}{*}{ Hepatotoxicity+ cancer drug+phyto* } & PubMed & 31 \\
\hline & ISI & 20 \\
\hline \multirow{2}{*}{ Hepatotoxicity+ cancer drug+herb* } & PubMed & 35 \\
\hline & ISI & 47 \\
\hline \multirow{2}{*}{$\begin{array}{l}\text { Hepatotoxicity+ chemotherapy + } \\
\text { medicinal plant }\end{array}$} & PubMed & 4 \\
\hline & ISI & 4 \\
\hline \multirow{2}{*}{ Hepatotoxicity+ chemotherapy + phyto* } & PubMed & 10 \\
\hline & ISI & 5 \\
\hline \multirow{2}{*}{ Hepatotoxicity+ chemotherapy + herb* } & PubMed & 10 \\
\hline & ISI & 16 \\
\hline \multirow{2}{*}{$\begin{array}{l}\text { Hepatoprotective + cancer drug+ } \\
\text { medicinal plant }\end{array}$} & PubMed & 40 \\
\hline & ISI & 34 \\
\hline \multirow{2}{*}{ Hepatoprotective + cancer drug+ phyto* } & PubMed & 60 \\
\hline & ISI & 29 \\
\hline \multirow{2}{*}{ Hepatoprotective + cancer drug+ herb* } & PubMed & 39 \\
\hline & ISI & 36 \\
\hline \multirow{2}{*}{$\begin{array}{l}\text { Hepatoprotective + chemotherapy + } \\
\text { medicinal plant }\end{array}$} & PubMed & 4 \\
\hline & ISI & 3 \\
\hline \multirow{2}{*}{$\begin{array}{l}\text { Hepatoprotective + chemotherapy + } \\
\text { phyto* }\end{array}$} & PubMed & 4 \\
\hline & ISI & 4 \\
\hline \multirow{2}{*}{ Hepatoprotective + chemotherapy + herb* } & PubMed & 6 \\
\hline & ISI & 6 \\
\hline \multirow{2}{*}{ Total } & PubMed & 257 \\
\hline & ISI & 221 \\
\hline
\end{tabular}

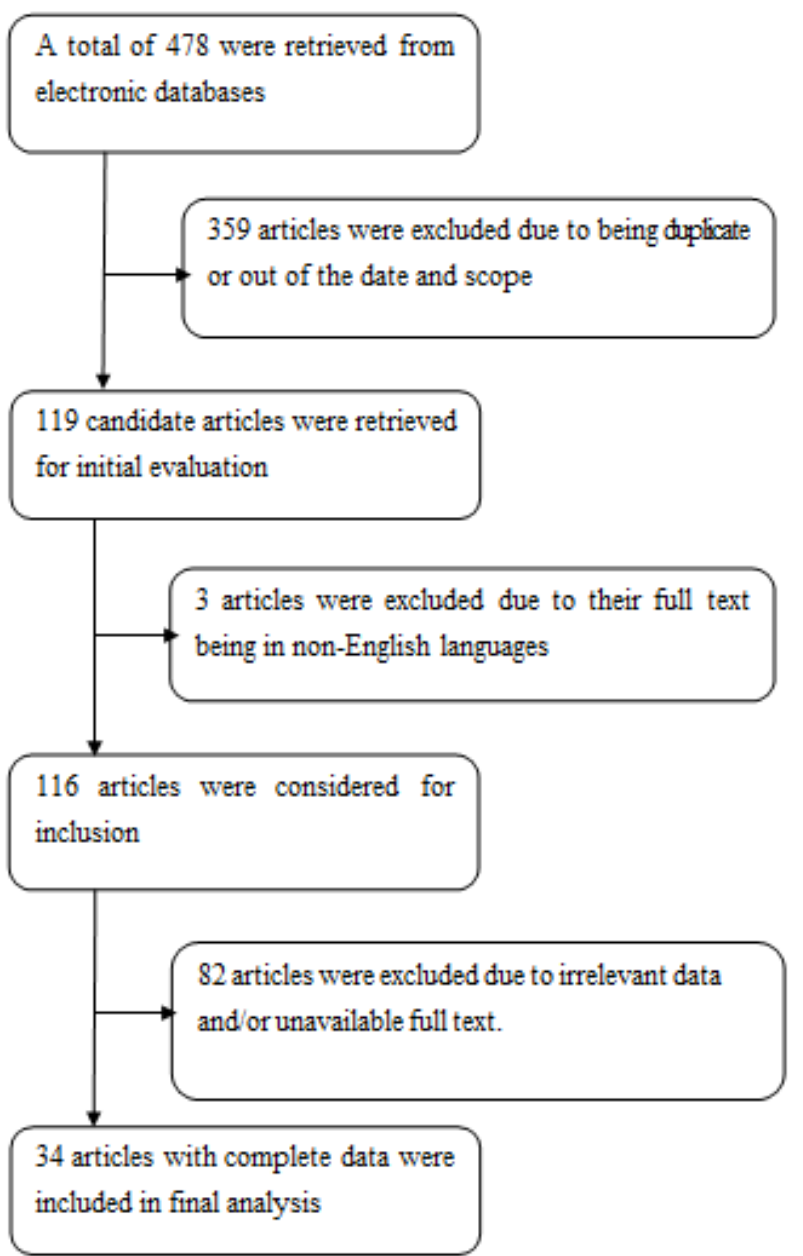

Fig. 1. Flowchart of the process of selecting the articles for final analysis 
Table 2: Medicinal plants that have an effect on cancer drug-induced hepatotoxicity

\begin{tabular}{|c|c|c|c|c|c|}
\hline References & Plants & $\begin{array}{l}\text { Cancer drug/ } \\
\text { treatment-inducing the } \\
\text { hepatotoxicity }\end{array}$ & Study Design & $\begin{array}{c}\text { Type of } \\
\text { administration }\end{array}$ & Main effects or mechanisms \\
\hline $\begin{array}{l}\text { Kumari et al. } \\
\text { (31) }\end{array}$ & $\begin{array}{l}\text { Phyllanthus } \\
\text { fraternus }\end{array}$ & $\begin{array}{c}\text { Cisplatin and } \\
\text { cyclophosphamide }\end{array}$ & $\begin{array}{l}\text { Experimental (in } \\
\text { vivo) }\end{array}$ & Aqueous extract & $\begin{array}{c}\text { Protective effect against mitochondrial } \\
\text { dysfunction induced by co-administration of } \\
\text { cisplatin and cyclophosphamide and did not } \\
\text { show any significant changes on } \\
\text { mitochondrial membrane bioenergetics }\end{array}$ \\
\hline $\begin{array}{l}\text { Dkhil et al. } \\
\text { (32) }\end{array}$ & $\begin{array}{l}\text { Azadirachta } \\
\text { indica }\end{array}$ & Cisplatin & $\begin{array}{c}\text { Experimental (in } \\
\text { vivo) }\end{array}$ & $\begin{array}{l}\text { Methanolic neem } \\
\text { leaves extract }\end{array}$ & $\begin{array}{l}\text { Reducing oxidative stress in liver by } \\
\text { decreasing malondialdehyde and nitric oxide } \\
\text { and improving glutathione content and } \\
\text { glutathione-S-transferase, glutathione } \\
\text { peroxidase (GPx), catalase, and superoxide } \\
\text { dismutase activities. }\end{array}$ \\
\hline
\end{tabular}

\begin{tabular}{|c|c|c|c|c|}
\hline Zarei and & & & & \\
\hline $\begin{array}{c}\text { Shivanandap } \\
\text { pa } \\
\text { (33) }\end{array}$ & $\begin{array}{l}\text { Decalepis } \\
\text { hamiltonii }\end{array}$ & Cyclophosphamide & $\begin{array}{l}\text { Experimental (in } \\
\text { vivo) }\end{array}$ & Aqueous extract \\
\hline
\end{tabular}

Mitigating cyclophosphamide-induced oxidative stress and reversing expression of genes for antioxidant enzymes.

Decreasing plasma malondialdehyde and increasing the superoxide dismutase and glutathione because less use of antioxidant compounds may not affect the production

$\begin{array}{cccc}\text { Zheng et al. } & \text { Camellia } & \text { Cisplatin } & \text { Experimental (in } \\ \text { (34) } & \text { sinensis } & \text { vivo) } & \text { Pu-erh tea powder }\end{array}$
and control of oxidative metabolites, or on the other hand, the excessive use of these plants and their compounds has adverse effects on the anticancer and apoptotic effects of anticancer drugs, oxidase (GSH-PX) levels and GSH-PX/MDA ratio

\begin{tabular}{|c|c|c|c|c|c|}
\hline $\begin{array}{l}\text { Huang et al. } \\
\text { (35) }\end{array}$ & $\begin{array}{c}\text { Antrodia } \\
\text { cinnamomea }\end{array}$ & Cisplatin & $\begin{array}{l}\text { Experimental (in } \\
\text { vivo) }\end{array}$ & Aqueous extract & $\begin{array}{l}\text { Reducing cisplatin-induced hepatic } \\
\text { inflammation and cell death. }\end{array}$ \\
\hline $\begin{array}{l}\text { Devi and } \\
\text { Mazumder } \\
\quad(36)\end{array}$ & $\begin{array}{l}\text { Curcuma } \\
\text { caesia Roxb. }\end{array}$ & Cyclophosphamide & $\begin{array}{l}\text { Experimental (in } \\
\text { vivo) }\end{array}$ & Methanolic extract & $\begin{array}{l}\text { Causing a decrease in aspartate } \\
\text { aminotransferase, alanine } \\
\text { aminotransferase, and peroxidation as } \\
\text { well as an increase in the level of } \\
\text { endogenous antioxidants such as } \\
\text { glutathione and glutathione reductase }\end{array}$ \\
\hline $\begin{array}{l}\text { El-Naggar et } \\
\text { al. (37) }\end{array}$ & $\begin{array}{l}\text { Rosmarinus } \\
\text { officianalis }\end{array}$ & Cyclophosphamide & $\begin{array}{l}\text { Experimental (in } \\
\text { vivo) }\end{array}$ & Methanolic extract & $\begin{array}{l}\text { Lowering level of aspartate } \\
\text { aminotransferase and lipid profile and } \\
\text { minimizing the histological damage }\end{array}$ \\
\hline Tuorkey (38) & Nigella sativa & Cyclophosphamide & $\begin{array}{l}\text { Experimental (in } \\
\text { vivo) }\end{array}$ & Oil & Protecting DNA \\
\hline Ladas (39) & $\begin{array}{l}\text { Silybum maria } \\
\text { num }\end{array}$ & $\begin{array}{l}\text { Methotrexate, } \\
\text { Mercaptopurine and } \\
\text { Vincristine }\end{array}$ & Clinical trial & $\begin{array}{l}\text { Capsule contain } \\
\text { powder }\end{array}$ & $\begin{array}{c}\text { Reducing serum levels of Aspartate } \\
\text { aminotransferase (AST) and Alanine } \\
\text { Aminotransferase (ALT) after } \\
\text { chemotherapy }\end{array}$ \\
\hline $\begin{array}{l}\text { McBride et al. } \\
\quad(40)\end{array}$ & $\begin{array}{l}\text { Silybum maria } \\
\text { num }\end{array}$ & $\begin{array}{l}\text { Daunorubicin and } \\
\text { cytarabine }\end{array}$ & Case-report & Extract & $\begin{array}{l}\text { Returning serum levels of AST and ALT } \\
\text { after chemotherapy and Anaplastic } \\
\text { lymphoma kinase (ALK) to the baseline } \\
\text { before start of chemotherapy }\end{array}$ \\
\hline Lata et al. (41) & $\begin{array}{l}\text { Phyllanthus } \\
\text { fraternus }\end{array}$ & Cyclophosphamide & $\begin{array}{l}\text { Experimental (in } \\
\text { vivo) }\end{array}$ & Aqueous extract & $\begin{array}{c}\text { Inhibition of lipid peroxidation and } \\
\text { augmentation of endogenous } \\
\text { antioxidants }\end{array}$ \\
\hline $\begin{array}{l}\text { Ahmadipour } \\
\text { et al. (42) }\end{array}$ & $\begin{array}{l}\text { Zataria } \\
\text { Multiflora } \\
\text { Boiss }\end{array}$ & Cisplatin & $\begin{array}{l}\text { Experimental (in } \\
\text { vivo) }\end{array}$ & Methanolic extract & $\begin{array}{l}\text { Reducing the level of AST, ALT and ALP } \\
\text { serum activity;inhibiting lipid } \\
\text { peroxidation and protein } \\
\text { carbonylation;restoring antioxidant } \\
\text { enzymes (SOD, CAT, and GSH-Px); } \\
\text { elevating glutathione level }\end{array}$ \\
\hline Tag et al. (43) & Morus nigra & Methotrexate & $\begin{array}{l}\text { Experimental (in } \\
\text { vivo) }\end{array}$ & Ethanolic extract & $\begin{array}{c}\text { Reducing activity of AST, ALT, ALP and } \\
\text { LDH }\end{array}$ \\
\hline Zhu et al. (44) & Panax (Ginseng) & Cyclophosphamide & $\begin{array}{l}\text { Experimental (in } \\
\text { vivo) }\end{array}$ & $\begin{array}{l}\text { Compounds, } \\
\text { including } \\
\text { ginsenoside }\end{array}$ & $\begin{array}{l}\text { Reversing GSH metabolism and primary } \\
\text { bile acids synthesis and NRF 2, one of the } \\
\text { regulatory elements of the expression of } \\
\text { GCLC, GCLM, GS, GST, NTCP and MRP3 }\end{array}$ \\
\hline $\begin{array}{l}\text { Ettaya et al. } \\
\quad(45)\end{array}$ & $\begin{array}{l}\text { Marrubium } \\
\text { vulgare }\end{array}$ & Cyclophosphamide & $\begin{array}{l}\text { Experimental (in } \\
\text { vivo) }\end{array}$ & Aqueous extract & $\begin{array}{c}\text { Inhibiting lipid peroxidation, and } \\
\text { increasing enzymatic defense system } \\
\text { (SOD, CAT, GPx) against oxidative stress. }\end{array}$ \\
\hline $\begin{array}{l}\text { Sheweita et al. } \\
\quad(46)\end{array}$ & $\begin{array}{l}\text { Foeniculum } \\
\text { vulgare }\end{array}$ & Cyclophosphamide & $\begin{array}{l}\text { Experimental (in } \\
\text { vivo) }\end{array}$ & Essential oils & $\begin{array}{l}\text { Restoring antioxidant enzymes (SOD, } \\
\text { CAT, GR, GST, and GPx) }\end{array}$ \\
\hline $\begin{array}{l}\text { Famurewa et } \\
\text { al. (47) }\end{array}$ & Cocos nucifera & Methotrexate & $\begin{array}{l}\text { Experimental (in } \\
\text { vivo) }\end{array}$ & Kernel oil & $\begin{array}{l}\text { Increasing serum activities of oxidative stress } \\
\text { markers (SOD, CAT, GPx and GSH) and } \\
\text { decreasing lipid peroxidation }\end{array}$ \\
\hline
\end{tabular}




\section{Medicinal plants, compounds and derivatives that effect cancer drug-induced hepatotoxicity}

Plants can help reduce hepatotoxicity through various mechanisms (Table 2).

There are numerous plant compounds for the treatment of chemotherapy-induced nephrotoxicity in patients that, in addition to protecting the liver against toxic substances, prevent necrosis as well. Plants can help reduce hepatotoxicity through various mechanisms (Table $3)$.

\section{Mechanisms of hepatoprotective and anti- hepatotoxicity properties of medicinal herbs}

Phytochemicals can exert their hepatoprotective properties through essential oils, phenyl compounds, monoterpenoids, coumarins, diterpenoids, alkaloids, triterpenoids, steroids, and others. These compounds inhibit oxidative stress-inducing agents, damage to proteins and DNA, and lipid peroxidation, and therefore lead to the formation of highly immunogenic molecules, amplification of the inflammatory response, and induction of necroapoptosis of hepatocytes. Reactive oxygen species (ROS) also contributes to the production of the TGF$\beta$ pro-fibrogenic mediator from Kupffer cells and the circulating inflammatory cells and activates hepatic stellate cells directly, which triggers fibrosis (63). In addition to protecting the liver against anticancer drugs, medicinal plants and plant compounds can also protect the liver against other drugs $(64,65)$ and toxic substances $(66-69)$ by exerting their antioxidant activity. These natural treatments can also exert anticancer effects themselves by inducing growth arrest and triggering pro-apoptotic death in liver cells (70). Some plants, such as Lindera obtusiloba, help protect the liver through the IGF-1 and NFkB signaling pathways by inhibiting critical receptor tyrosine kinases that contribute to the progression of human hepatocellular carcinoma (71). In addition, treatment with phytoestrogen prevents increase in levels of malondialdehyde, nitric oxide, ALT, and AST, and increases the activity of superoxide dismutase (SOD), glutathione peroxidase (GPx), and catalase. It also increases levels of glutathione (GSH) and glutathione reductase (GR). Through such mechanisms, they protect against mitochondrial damage and cell apoptosis (32,36, 72,73). Some medicinal plants also exhibit anti-nephrotoxicity properties by inhibiting inflammatory processes (decreasing NFkB-mediated hepatic inflammation) and decreasing cell necrosis $(35,74)$.

At the cellular level, it can be argued that mitochondrial damage is one of the most significant consequences due to the increase of ROS in chemotherapy, which occurs due to structural changes, increased mitochondrial permeability, and reduced mitochondria membrane, which then disrupts normal cell function (75). But despite the protective and antinecrotic properties, certain medicinal plants or their derivatives at high doses can cause cytotoxicity in liver cells $(76,77)$, and in some cases, herbal self-care is used for treating these toxicities (78). Therefore, the use of medicinal plants should be supervised by a specialist and physician and special measures should be taken for patients with liver disease.

\section{Complications and limitations of medicinal herb use with chemotherapy}

Anticancer drugs have major adverse effects through oxidative stress pathways, inflammatory processes, and cell apoptosis. Plants and their derivatives mainly protect the liver against free radicals and inflammatory cytokines.

They can also induce their properties by increasing the content of glutathione and modulating various signal transduction pathways (79). However, it should be noted that the use of antioxidants and even some herbal extracts for the prevention and reduction of tissue toxicities should be supervised by a physician, and that they should be taken with caution (80). Because studies show that polyphenols in green tea (as a plant with high antioxidant properties) and alkaloids and aristolochic acids in some plants can cause inflammation and nephrotoxicity, these can cause liver dysfunction and apoptosis of normal liver cells (81-84). However, because of the numerous side effects of anticancer drugs such as hepatotoxicity, bone marrow suppression, and nephrotoxicity, it is necessary to seek out alternative anti-cancer methods. This alternative method can be use of herbal (85) or chemical drugs. However, the use of antioxidant compounds with anticancer drugs is still debatable because some studies suggest that excessive use of antioxidant compounds can interfere with the process of chemotherapy and cancer treatment (86). Other studies have demonstrated the beneficial effects of antioxidants and a decrease in damage to normal cells and complications of chemotherapy by these compounds (87). Even so, interaction of anticancer drugs with herbal drugs can cause severe impairments in the patient that cause certain problems in the treatment process and the immune system, including nausea and vomiting, alopecia, fatigue, inflammation, peripheral neuropathy and pain (88), and even in some cases, hepatotoxicity in cancer patients (89). In addition, herbal medication constituents that exert hepatoprotective activity are poorly absorbed after oral administration; methods that can improve their bioavailability must be developed and active plants must be isolated (63). It is essential to determine the optimal effective dosage without toxicity in the use of these drugs, because small amounts of antioxidant compounds may not affect the production and control of oxidative metabolites, while excessive use of these plants and their compounds has adverse effects on the anticancer and anti-apoptotic effects of anticancer drugs. 
Table 3: Medicinal plant compounds and derivatives shown to have an effect on cancer drug-induced hepatotoxicity

\begin{tabular}{|c|c|c|c|c|c|}
\hline \multicolumn{6}{|c|}{ Medicinal plants compounds } \\
\hline References & Herbal compounds / derivatives & $\begin{array}{l}\text { Cancer drugs that induced } \\
\text { hepatotoxicity }\end{array}$ & Study Design & $\begin{array}{c}\text { Type of } \\
\text { administration }\end{array}$ & Main effects or mechanisms \\
\hline Liu et al. (48) & $\begin{array}{l}\text { Traditional Chinese medicine } \\
\text { composed of Xiao-Chai-HuTang, } \\
\text { Huang-Lian-Jie-Du-Tang or Yin- } \\
\text { Chen-Wu-Ling-San }\end{array}$ & $\begin{array}{l}\text { Ara-C, bleomycin, carboplatin, } \\
\text { cisplatin, cyclophosphamide, } \\
\text { dacarbazine, doxorubicin, } \\
\text { etoposide, fluorouracil, } \\
\text { formoxol, gemcitabine, } \\
\text { ifosfamide, mitoxantrone, } \\
\text { methotrexate, mitomycin } \\
\text { C, oxaliplatin, taxol and } \\
\text { taxotere (with potential } \\
\text { hepatotoxicity); arimidex,CPT- } \\
\text { 11, faslodex, herceptin, } \\
\text { navelbine, tamoxifen, UFUR }\end{array}$ & Case-control & $\begin{array}{l}\text { Extracts in the } \\
\text { form } \\
\text { of powders }\end{array}$ & $\begin{array}{l}\text { Have protective effect by } \\
\text { reducing serum levels of AST } \\
\text { and ALT after chemotherapy }\end{array}$ \\
\hline $\begin{array}{l}\text { Gnanasekar } \\
\text { an et al. (49) }\end{array}$ & $\begin{array}{l}\text { Vivartana composed of Cassia } \\
\text { auriculata (leaves), Syzygium } \\
\text { cumini (seed coat), Thespesia } \\
\text { populnea (bark), Piper longum } \\
\text { (dried fruit) }\end{array}$ & Cyclophosphamide & $\begin{array}{l}\text { Experimental (in } \\
\text { vivo) }\end{array}$ & Powder & $\begin{array}{l}\text { Exert its hepatoprotective } \\
\text { properties by regulating AST } \\
\text { and AST }\end{array}$ \\
\hline $\begin{array}{l}\text { Gong et al. } \\
\text { (50) }\end{array}$ & $\begin{array}{l}\text { Chinese ZengmianYiliu granule } \\
\text { composed of Radix Astragali } \\
\text { Mongolic, Radix Codonopsis, } \\
\text { Radix Rehmanniae, Herba } \\
\text { Scutellariae Barbatae, Rhizoma } \\
\text { Atractylodis Macrocephalae }\end{array}$ & Cisplatin & $\begin{array}{l}\text { Experimental (in } \\
\text { vivo) }\end{array}$ & Ethanolic extract & $\begin{array}{l}\text { Prevented the elevation of the } \\
\text { ALT and AST levels as well as } \\
\text { the reduction of total } \\
\text { glutathione (T-GSH), GSH, and } \\
\text { glutathione S-transferase (GST) }\end{array}$ \\
\hline Li et al. (51) & $\begin{array}{l}\text { Haoqin Qingdan consist of } \\
\text { Artemisinin,bambooshavings, } \\
\text { Pinellia ternata, Indian buead, } \\
\text { Scutellaria baicalensis, Auran- } \\
\text { tii fructus, Aurantii nobilis } \\
\text { pericarpium, and Biyu powder }\end{array}$ & Cyclophosphamide & $\begin{array}{l}\text { Experimental (in } \\
\text { vitro) }\end{array}$ & Aqueous Extract & $\begin{array}{l}\text { Attenuated SOD and GSH } \\
\text { elevated levels; inhibit } \\
\text { apoptosis by reducing cleaved } \\
\text { caspase-3 expression }\end{array}$ \\
\hline \multicolumn{6}{|c|}{ Medicinal plants compounds' derivatives } \\
\hline $\begin{array}{l}\text { Oyagbemi et } \\
\text { al. (52) }\end{array}$ & Gallic acid & Cyclophosphamide & $\begin{array}{l}\text { Experimental (in } \\
\text { vivo) }\end{array}$ & $\begin{array}{l}\text { Herbal } \\
\text { derivative }\end{array}$ & $\begin{array}{c}\text { Led to activation of catalase } \\
\text { and GSH-S-transferase by } \\
\text { increasing antioxidant defense, } \\
\text { such as elevating the level of } \\
\text { GSH }\end{array}$ \\
\hline $\begin{array}{l}\text { Olayinka } \\
\text { (53) }\end{array}$ & Gallic acid & Cyclophosphamide & $\begin{array}{l}\text { Experimental (in } \\
\text { vivo) }\end{array}$ & $\begin{array}{l}\text { Herbal } \\
\text { derivative }\end{array}$ & $\begin{array}{l}\text { Ameliorated against the } \\
\text { decrease in SOD,catalase and } \\
\text { GST activities. Also has } \\
\text { antioxidant activity }\end{array}$ \\
\hline $\begin{array}{l}\text { Wu et al. } \\
\text { (54) }\end{array}$ & Paeonol & Epirubicin & $\begin{array}{l}\text { Experimental (in } \\
\text { vivo) }\end{array}$ & $\begin{array}{l}\text { Herbal } \\
\text { derivative }\end{array}$ & $\begin{array}{l}\text { Inhibiting the PI3K/Akt/NF-kB } \\
\text { pathway through 4T1-tumor } \\
\text { bearing mice }\end{array}$ \\
\hline $\begin{array}{l}\text { Gao et al. } \\
\quad(55)\end{array}$ & Ginsenoside Rg1 & Cisplatin & $\begin{array}{l}\text { Experimental (in } \\
\text { vivo) }\end{array}$ & Ginsing extract & $\begin{array}{l}\text { The antioxidant proteins } \\
\text { associated with the Nrf2 } \\
\text { signaling pathway in mice } \\
\text { increased } \\
\end{array}$ \\
\hline $\begin{array}{l}\text { Abdelmegui } \\
\text { d et al. (56) }\end{array}$ & Silymarin & Cisplatin & $\begin{array}{l}\text { Experimental (in } \\
\text { vivo) }\end{array}$ & $\begin{array}{l}\text { Herbal } \\
\text { derivative }\end{array}$ & $\begin{array}{l}\text { Reversed changes in liver } \\
\text { where most hepatocytes } \\
\text { appeared diminutive with } \\
\text { vacuolated cytoplasm, dilated } \\
\text { sinusoids and organelle } \\
\text { disorganization }\end{array}$ \\
\hline $\begin{array}{l}\text { Hagag et al. } \\
\text { (57) }\end{array}$ & Silymarin & Methotrexate & Clinical trial & $\begin{array}{c}\text { Herbal } \\
\text { derivative }\end{array}$ & $\begin{array}{l}\text { Reducing the level of ALT and } \\
\text { AST and alkaline phosphatase }\end{array}$ \\
\hline $\begin{array}{l}\text { Olayinka et } \\
\text { al. (58) }\end{array}$ & Quercetin & Melphalan & $\begin{array}{l}\text { Experimental (in } \\
\text { vivo) }\end{array}$ & $\begin{array}{l}\text { Herbal } \\
\text { derivative }\end{array}$ & $\begin{array}{l}\text { Hepatic ascorbic acid, GSH, } \\
\text { glutathione-S-transferase, SOD, } \\
\text { and catalase activities } \\
\text { decreased; reestablished } \\
\text { hepatic antioxidant status and } \\
\text { lipid peroxidation }\end{array}$ \\
\hline $\begin{array}{l}\text { Schwingel et } \\
\text { al. (49) }\end{array}$ & $\begin{array}{l}\text { Resveratrol, rutin, quercetin, and } \\
\text { quercetin nanoemulsion }\end{array}$ & Oxaliplatin & $\begin{array}{l}\text { Experimental (in } \\
\text { vivo) }\end{array}$ & $\begin{array}{c}\text { Herbal } \\
\text { derivative }\end{array}$ & $\begin{array}{l}\text { Reduced immunopositivity for } \\
\text { the apoptosis marker caspase- } 3\end{array}$ \\
\hline Lin et al. (60) & Glutathione & Oxaliplatin & $\begin{array}{l}\text { Experimental (in } \\
\text { vivo) }\end{array}$ & $\begin{array}{c}\text { Herbal } \\
\text { derivative }\end{array}$ & $\begin{array}{l}\text { Serum ALT, MDA and AST } \\
\text { level were decreased. }\end{array}$ \\
\hline $\begin{array}{l}\text { Mehrzadi et } \\
\text { al. (61) }\end{array}$ & Berberine & Methotrexate & $\begin{array}{l}\text { Experimental (in } \\
\text { vivo) }\end{array}$ & $\begin{array}{l}\text { Herbal } \\
\text { derivative }\end{array}$ & $\begin{array}{c}\text { Serum levels of AST, MDA and } \\
\text { ALT decreased and GSH level } \\
\text { as well as GPx activity } \\
\text { increased }\end{array}$ \\
\hline $\begin{array}{l}\text { Mir et al. } \\
(62)\end{array}$ & Zingerone & Cyclophosphamide & $\begin{array}{l}\text { Experimental (in } \\
\text { vivo) }\end{array}$ & $\begin{array}{l}\text { Zingiber } \\
\text { officinale } \\
\text { derivative }\end{array}$ & $\begin{array}{l}\text { Restoration of hepatic markers, } \\
\text { amelioration of lipid profile, } \\
\text { and improvement of } \\
\text { antioxidant status and DNA } \\
\text { damage }\end{array}$ \\
\hline
\end{tabular}




\section{Conclusion}

Phytotherapy can be used as an effective and efficient approach to treat hepatotoxicity caused by anticancer drugs, and prevent several complications in the liver. Plants and their compounds and derivatives can protect the liver against anticancer drugs and are used as an alternative to chemical treatments mainly due to their antioxidant and anti-inflammatory properties.

However, it is necessary to develop evidence based on human studies to obtain more reliable results regarding the safety and efficacy of herbal drugs in the chemotherapy process. More research must be done to accurately determine the safety and efficacy of potential herb-drug interactions upon concurrent administration.

\section{Authors' contribution}

SHS and SA have done the collection of literature. All authors prepared the content of the manuscript, provided inputs, and approved the final version.

\section{Competing Interest}

The authors declare that they have no competing interest.

\section{References}

1. World Health Organization. Cancer: Fact sheet $N^{\circ} 297$ Genowa: WHO; 2016 [updated February 2015; cited 2016 7/3/2016]. Available from: http://www.who.int/mediacentre/factsheets/fs297/en

2. Kufe DW, Hait W, Holland JF, Frei E, Pollock RE. Holland Frei cancer medicine 8: PMPH-USA; 2010.

3. Edwards BJ, Raisch DW, Saraykar SS, Sun M, Hammel JA, Tran HT, et al. Hepatotoxicity with Vismodegib: An MD Anderson Cancer Center and research on adverse drug events and reports project. Drugs in R\&D. 2017;17(1):211-8. $\quad$ https://doi.org/10.1007/s40268-016$\underline{0168-2}$

4. Sharma A, Houshyar R, Bhosale P, Choi J-I, Gulati R, Lall C. Chemotherapy induced liver abnormalities: an imaging perspective. Clinical and Molecular Hepatology.

https://doi.org/10.3350/cmh.2014.20.3.317

5. Grigorian A, O'Brien CB. Hepatotoxicity Secondary to Chemotherapy. Journal of Clinical and Translational Hepatology. 2014;2(2):95-102.

6. Vincenzi B, Armento G, Spalato Ceruso M, Catania G, Leakos M, Santini D, et al. Drug-induced hepatotoxicity in cancer patients - implication for treatment. Expert Opinion on Drug Safety. 2016;15(9):1219-38. https://doi.org/10.1080/14740338.2016.1194824

7. Nikfarjam M, Dehkordi KS, Aghaei A, Rahimian G. Efficacy of hypnotherapy in conjunction with pharmacotherapy and pharmacotherapy alone on the quality of life in patients with irritable bowel syndrome. Govaresh. 2013;18(3):149-56.
8. Dehkordi KS, Nikfarjam M, Sanaei S. Effectiveness of mindfulness-based stress reduction training and drug therapy on quality of life in patients with irritable bowel syndrome in Shahrekord. Life Science Journal. 2014;11(9):445-9.

9. Hasanpour-Dehkordi A, Jivad N, Solati K. Effects of yoga on physiological indices, anxiety and social functioning in multiple sclerosis patients: A randomized trial. Journal of Clinical and Diagnostic Research. 2016;10(6):VC01-VC5.

10. Shahbazi K, Solati-Dehkordi K, Dehkordi AH. Comparison of hypnotherapy and standard medical treatment alone on quality of life in patients with irritable bowel syndrome: A randomized control trial. Journal of Clinical and Diagnostic Research. 2016;10(5):OC01-OC4. https://doi.org/10.7860/JCDR/2016/17631.7713

11. Solati K. Effectiveness of cognitive-behavior group therapy, psycho-education family, and drug therapy in reducing and preventing recurrence of symptoms in patients with major depressive disorder. Journal of Chemical and Pharmaceutical Sciences. 2016;9(4):34148.

12. Noghabi AAA, Zandi M, Mehran A, Alavian SM, Dehkordi AH. The effect of education on quality of life in patients under interferon therapy. Hepatitis Monthly. 2010;10(3):218-22.

13. Solati K, Mousavi M, Kheiri S, Hasanpour-Dehkordi A. The effectiveness of mindfulness-based cognitive therapy on psychological symptoms and quality of life in systemic lupus erythematosus patients: A randomized controlled trial. Oman Medical Journal. 2017;32(5):378-85. https://doi.org/10.5001/omj.2017.73

14. Rouhi-Boroujeni H, Asadi-Samani M, Moradi MT. A review of the medicinal plants effective on headache based on the ethnobotanical documents of Iran. Der Pharmacia Lettre. 2016;8(3):37-42.

15. Kooti W, Moradi M, Ali-Akbari S, Sharafi-Ahvazi N, Asadi-Samani M, Ashtary-Larky D. Therapeutic and pharmacological potential of Foeniculum vulgare Mill: A review. Journal of Herbmed Pharmacology. 2015;4(1):19.

16. Mohsenzadeh A, Ahmadipour S, Ahmadipour S, AsadiSamani M. Iran's medicinal plants effective on fever in children: A review. Der Pharmacia Lettre. 2016;8(1):129-34.

17. Parsaei $P$, Bahmani $M$, Naghdi N, Asadi-Samani $M$, Rafieian-Kopaei MM, Boroujeni S. Shigellosis phytotherapy: A review of the most important native medicinal plants in Iran effective on Shigella. Der Pharmacia Lettre. 2016;8(2):249-55.

18. Kooti W, Ghasemiboroon M, Asadi-Samani M, Ahangarpoor A, Zamani M, Amirzargar A, et al. The effect of Halcoholic extract of celery leaves on the delivery rate (fertilization and stillbirths), the number, weight and sex ratio of rat off spring. Advances in Environmental Biology. 2014;8(10):824-30.

19. Hosseini Z, Lorigooini Z, Rafieian-Kopaei M, Shirmardi $\mathrm{H}$, Solati K. A review of botany and pharmacological effect and chemical composition of Echinophora species growing in Iran. Pharmacognosy Research. 2017;9(4):305-12. https://doi.org/10.4103/pr.pr 22 17

20. Heidarian E, Movahed-Mohammadi G, Saffari J, Ghatreh-Samani K. Protective effect of hydroethanolic extract of cress against hepatotoxicity due to acetaminophen in rats. Journal of Mazandaran University of Medical Sciences. 2013;23(102):78-90. 
21. Heidari-Soreshjani S, Asadi-Samani M, Yang Q, SaeediBoroujeni A. Phytotherapy of nephrotoxicity-induced by cancer drugs: an updated review. Journal of Nephropathology. https://doi.org/10.15171/jnp.2017.41

22. Memarzadeh E, Luther T, Heidari-Soureshjani S. Effect and Mechanisms of Medicinal Plants on Dry Eye Disease: A Systematic Review. Journal of Clinical and Diagnostic Research. 2018;12(9):NE1-NE4. https://doi.org/10.7860/JCDR/2018/36409.12042

23. Shabanian G, Heidari-Soureshjani S, Rafieian-Kopaei M, Saadat M, Shabanian M. Therapeutic effects of Quercus persica 1 fruit skin on healing of second-degree burn wounds in animal model. Journal of Zanjan University of Medical Sciences and Health Services. 2017;25(113):81-92.

24. Shabanian S, Khalili S, Lorigooini Z, Malekpour A, Heidari-Soureshjani S. The effect of vaginal cream containing ginger in users of clotrimazole vaginal cream on vaginal candidiasis. Journal of Advanced Pharmaceutical Technology \& Research. 2017;8(2):80-4.

25. Shirani M, Raeisi R, Heidari-Soureshjani S, AsadiSamani M, Luther T. A review for discovering hepatoprotective herbal drugs with least side effects on kidney. Journal of Nephropharmacology. 2017;6(2).

26. Yavangi M, Rabiee S, Nazari S, Farimani-Sanoee M, Amiri I, Bahmanzadeh M, et al. Comparison of the effect of oestrogen plus Foeniculum vulgare seed and oestrogen alone on increase in endometrial thickness in infertile women. Journal of Clinical and Diagnostic Research. 2018;12(1):QC01 - QC4. https://doi.org/10.7860/ ICDR/2018/30164.11020

27. Heidari-Soreshjani S, Asadi-Samani M, Yang Q, SaeediBoroujeni A. Phytotherapy of nephrotoxicity-induced by cancer drugs: An updated review. Journal of Nephropathology. https://doi.org/10.15171/jnp.2017.41

28. Shirani-Boroujeni M, Heidari-Soureshjani S, Keivani Hafshejani Z. Impact of oral capsule of Peganum harmala on alleviating urinary symptoms in men with benign prostatic hyperplasia; a randomized clinical trial. Journal of Renal Injury Prevention. 2017;6(2):12731. https://doi.org/10.15171/jrip.2017.25

29. Nikfarjam M, Rakhshan R, Ghaderi H. Comparison of effect of Lavandula officinalis and venlafaxine in treating depression: A double blind clinical trial. Journal of Clinical and Diagnostic Research : JCDR. 2017;11(7):KC01-KC4.

https://doi.org/10.7860/JCDR/2017/20657.10233

30. Solati K, Heidari-Soureshjani S, Luther T, Asadi-Samani M. Iranian medicinal plants effective on sexual disorders: A systematic review. International Journal of Pharmaceutical Sciences and Research. 2017;8(6):241520.

31. Kumari KK, Setty OH. Protective effect of Phyllanthus fraternus against mitochondrial dysfunction induced by co-administration of cisplatin and cyclophosphamide. Journal of Bioenergetics and Biomembranes. 2012;44(1):179-88. https://doi.org/10.1007/s10863-0129423-6

32. Dkhil MA, Al-Quraishy S, Aref AM, Othman MS, El-Deib KM, Moneim AEA. The potential role of Azadirachta indica treatment on cisplatin-induced hepatotoxicity and oxidative stress in female rats. Oxidative Medicine and Cellular Longevity. 2013; 741817.

33. Zarei M, Shivanandappa T. Amelioration of cyclophosphamide-induced hepatotoxicity by the root extract of Decalepis hamiltonii in mice. Food and Chemical Toxicology. 2013;57:179-84. https://doi.org/10.1016/j.fct.2013.03.028

34. Zheng XN, Wang XW, Li LY, Xu ZW, Huang HY, Zhao JS, et al. Pu-erh tea powder preventive effects on cisplatininduced liver oxidative damage in Wistar rats. Asian Pacific Journal of Cancer Prevention. 2014;15(17):738994. https://doi.org/10.7314/APJCP.2014.15.17.7389

35. Huang TH, Chiu YH, Chan YL, Wang H, Li TL, Liu CY, et al. Antrodia cinnamomea alleviates cisplatin-induced hepatotoxicity and enhances chemo-sensitivity of line-1 lung carcinoma xenografted in BALB/cByJ mice. Oncotarget. https://doi.org/10.18632/oncotarget.4348

36. Devi HP, Mazumder PB. Methanolic extract of Curcuma caesia Roxb. Prevents the toxicity caused by cyclophosphamide to bone marrow cells, liver and kidney of mice. Pharmacognosy Research. 2016;8(1):439. https://doi.org/10.4103/0974-8490.171106

37. El-Naggar SA, Abdel-Farid IB, Germoush MO, Elgebaly HA, Alm-Eldeen AA. Efficacy of Rosmarinus officinalis leaves extract against cyclophosphamide-induced hepatotoxicity. Pharmaceutical Biology. 2016;54(10):2007-16. https://doi.org/10.3109/13880209.2015.1137954

38. Tuorkey MJ. Therapeutic potential of Nigella sativa oil against cyclophosphamide-induced DNA damage and hepatotoxicity. Nutrition and Cancer. 2017;69(3):498504. https://doi.org/10.1080/01635581.2017.1285408

39. Ladas EJ, Kroll DJ, Oberlies NH, Cheng B, Ndao DH, Rheingold SR, et al. A randomized, controlled, doubleblind, pilot study of milk thistle for the treatment of hepatotoxicity in childhood acute lymphoblastic leukemia (ALL). Cancer. 2010;116(2):506-13. https://doi.org/10.1002/cncr.24723

40. McBride A, Augustin KM, Nobbe J, Westervelt P. Silybum marianum (milk thistle) in the management and prevention of hepatotoxicity in a patient undergoing reinduction therapy for acute myelogenous leukemia. Journal of Oncology Pharmacy Practice. 2012;18(3):3605. https://doi.org/10.1177/1078155212438252

41. Lata S, Singh S, NathTiwari K, Upadhyay R. Evaluation of the antioxidant and hepatoprotective effect of Phyllanthus fraternus against a chemotherapeutic drug cyclophosphamide. Applied Biochemistry and Biotechnology. 2014;173(8):2163-73. https://doi.org/10.1007/s12010-014-1018-8

42. Ahmadipour A, Sharififar F, Nakhaipour F, Samanian M, Karami-Mohajeri S. Hepatoprotective effect of Zataria Multiflora Boiss on cisplatin-induced oxidative stress in male rat. Journal of Medicine and Life. 2015;8(Spec Iss 4):275-81.

43. Tag HM. Hepatoprotective effect of mulberry (Morus nigra) leaves extract against methotrexate induced hepatotoxicity in male albino rat. BMC Complementary and Alternative Medicine. 2015;15:252. https://doi.org/10.1186/s12906-015-0744-y

44. Zhu H, Long MH, Wu J, Wang MM, Li XY, Shen H, et al. Ginseng alleviates cyclophosphamide-induced hepatotoxicity via reversing disordered homeostasis of glutathione and bile acid. Scientific Reports. 2015;5:17536. https://doi.org/10.1038/srep17536

45. Ettaya A, Dhibi S, Samout N, Elfeki A, Hfaiedh N. Hepatoprotective activity of white horehound (Marrubium vulgare) extract against cyclophosphamide toxicity in male rats. Canadian Journal of Physiology and Pharmacology. 2016;94(4):441-7. https://doi.org/10.1139/cjpp-2015-0405 
46. Sheweita SA, El-Hosseiny LS, Nashashibi MA. Protective effects of essential oils as natural antioxidants against hepatotoxicity induced by cyclophosphamide in mice. PLoS One. 2016;11(11):e0165667. https://doi.org/10.1371/ journal.pone.0165667

47. Famurewa AC, Folawiyo AM, Enohnyaket EB, AzubuikeOsu SO, Abi I, Obaje SG, et al. Beneficial role of virgin coconut oil supplementation against acute methotrexate chemotherapy-induced oxidative toxicity and inflammation in rats. Integrative Medicine Research. 2018;7(3):257-63.

https://doi.org/10.1016/j.imr.2018.05.001

48. Liu M-L, Chien L-Y, Tai C-J, Lin K-C, Tai C-J. Effectiveness of traditional chinese medicine for liver protection and chemotherapy completion among cancer patients. Evidence-Based Complementary and Alternative Medicine. 2011; 291843. https://doi.org/10.1093/ecam/nep185

49. Gnanasekaran S, Sakthivel KM, Chandrasekaran G. Immunostimulant and chemoprotective effect of vivartana, a polyherbal formulation against cyclophosphamide induced toxicity in Swiss albino mice. Journal of Experimental Therapeutics and Oncology. 2015;11(1):51-61.

50. Gong C, Qian L, Yang H, Ji LL, Wei H, Zhou WB, et al. Hepatotoxicity and pharmacokinetics of cisplatin in combination therapy with a traditional Chinese medicine compound of Zengmian Yiliu granules in ICR mice and SKOV-3-bearing nude mice. BMC Complementary and Alternative Medicine. 2015;15:283. https://doi.org/10.1186/s12906-015-0799-9

51. Li X, Li B, Jia Y. The Hepatoprotective effect of Haoqin Qingdan decoction against liver injury induced by a chemotherapeutic drug cyclophosphamide. EvidenceBased Complementary and Alternative Medicine. 2015;2015:978219-. https://doi.org/10.1155/2015/978219

52. Oyagbemi AA, Omobowale OT, Asenuga ER, Akinleye AS, Ogunsanwo RO, Saba AB. Cyclophosphamideinduced hepatotoxicity in Wistar Rats: The modulatory role of gallic acid as a hepatoprotective and chemopreventive phytochemical. International Journal of Preventive Medicine. https://doi.org/10.4103/2008-7802.177898

53. Olayinka ET, Ore A, Ola OS, Adeyemo OA. Ameliorative effect of gallic acid on cyclophosphamide-induced oxidative injury and hepatic dysfunction in rats. Medical Sciences (Basel, Switzerland). 2015;3(3):78-92. https://doi.org/10.3390/medsci3030078

54. Wu J, Xue X, Zhang B, Jiang W, Cao H, Wang R, et al. The protective effects of paeonol against epirubicin-induced hepatotoxicity in 4T1-tumor bearing mice via inhibition of the PI3K/Akt/NF-kB pathway. ChemicoBiological Interactions. 2016;244:1-8 https://doi.org/10.1016/i.cbi.2015.11.025

55. Gao Y, Chu S, Shao Q, Zhang M, Xia C, Wang Y, et al. Antioxidant activities of ginsenoside $\operatorname{Rg} 1$ against cisplatin-induced hepatic injury through Nrf2 signaling pathway in mice. Free Radical Research. 2017;51(1):113. https://doi.org/10.1080/10715762.2016.1234710

56. Abdelmeguid NE, Chmaisse $\mathrm{HN}$, Abou Zeinab NS. Silymarin ameliorates cisplatin-induced hepatotoxicity in rats: histopathological and ultrastructural studies. Pakistan Journal of Biological Sciences. 2010;13(10):46379. https://doi.org/10.3923/pjbs.2010.463.479

57. Hagag AA, Elgamsy MA, El-Asy HM, Mabrouk MM. Protective Role of silymarin on hepatic and renal toxicity induced by MTX based chemotherapy in children with acute lymphoblastic leukemia.
Mediterranean Journal of Hematology and Infectious Diseases. https://doi.org/10.4084/mihid.2016.043

58. Olayinka ET, Ore A, Ola OS, Adeyemo OA. Protective effect of quercetin on melphalan-induced oxidative stress and impaired renal and hepatic functions in rat. Chemotherapy Research and Practice. 2014; 936526. https://doi.org/10.1155/2014/936526

59. Schwingel TE, Klein CP, Nicoletti NF, Dora CL, Hadrich G, Bica CG, et al. Effects of the compounds resveratrol, rutin, quercetin, and quercetin nanoemulsion on oxaliplatininduced hepatotoxicity and neurotoxicity in mice. NaunynSchmiedeberg's Archives of Pharmacology. 2014;387(9):837-48. ～https://doi.org/10.1007/s00210-0140994-0

60. Lin $\mathrm{Y}, \mathrm{Li} \mathrm{Y,} \mathrm{Hu} \mathrm{X,} \mathrm{Liu} \mathrm{Z,} \mathrm{Chen} \mathrm{J,} \mathrm{Lu} \mathrm{Y,} \mathrm{et} \mathrm{al.} \mathrm{The}$ hepatoprotective role of reduced glutathione and its underlying mechanism in oxaliplatin-induced acute liver injury. Oncology Letters. 2018;15(2):2266-72.

61. Mehrzadi S, Fatemi I, Esmaeilizadeh M, Ghaznavi H, Kalantar H, Goudarzi M. Hepatoprotective effect of berberine against methotrexate induced liver toxicity in rats. Biomedicine \& Pharmacotherapy. 2018;97:233-9. https://doi.org/10.1016/j.biopha.2017.10.113

62. Mir BA, Amin I, Rehman MU, Razak R, Ali A, Baba OK, et al. Chemoprotective potentialo Zingerone (Vanillyl Acetone) in cyclophosphamide-induced hepatic toxicity. Pharmacognosy Magazine. 2018;14(57):S434-S9. https://doi.org/10.4103/pm.pm 17016

63. Farghali H, Canova NK, Zakhari S. Hepatoprotective properties of extensively studied medicinal plant active constituents: possible common mechanisms. Pharmaceutical Biology. 2015;53(6):781-91. https://doi.org/10.3109/13880209.2014.950387

64. Karami M, Salehi H, Naghshvar F. Study of histopathology and antioxidant activity of methanolic extract of Feijoa sellowiana against dosage induced by MDMA in mouse liver. Pharmacologyonline. 2008;3:31521.

65. Lina SMM, Ashab I, Ishtiaq Ahmed M, Shahriar M. Hepatoprotective activity of Asteracantha longifolia (Nees.) extract against anti-tuberculosis drugs induced hepatic damage in Sprague-Dawley rats. Pharmacologyonline. 2012;3:13-9.

66. Lin HM, Tseng HC, Wang CJ, Lin JJ, Lo CW, Chou FP. Hepatoprotective effects of Solanum nigrum Linn extract against $\mathrm{CCl} 4$-iduced oxidative damage in rats Chemico-Biological Interactions. 2008;171(3):283-93 https://doi.org/10.1016/j.cbi.2007.08.008

67. Pradeep K, Mohan CVR, Gobianand K, Karthikeyan S. Protective effect of Cassia fistula Linn. on diethylnitrosamine induced hepatocellular damage and oxidative stress in ethanol pretreated rats. Biological Research.

2010;43(1):113-25 https://doi.org/10.4067/S0716-97602010000100013

68. Jiang Y, Wang C, Li YY, Wang XC, An JD, Wang YJ, et al. Mistletoe alkaloid fractions alleviates carbon tetrachloride-induced liver fibrosis through inhibition of hepatic stellate cell activation via TGF-beta/Smad interference. Journal of Ethnopharmacology. 2014;158 Pt A:230-8.

69. Zhang W, Zhang X, Zou K, Xie J, Zhao S, Liu J, et al. Seabuckthorn berry polysaccharide protects against carbon tetrachloride-induced hepatotoxicity in mice: Via anti-oxidative and anti-inflammatory activities. Food and Function. 2017;8(9):3130-8. https://doi.org/10.1039/C7FO00399D 
70. Choedon T, Shukla SK, Kumar V. Chemopreventive and anti-cancer properties of the aqueous extract of flowers of Butea monosperma. Journal of Ethnopharmacology. 2010;129(2):208-13.

https://doi.org/10.1016/j.jep.2010.03.011

71. Freise C, Ruehl M, Erben U, Neumann U, Seehofer D, Kim KY, et al. A hepatoprotective Lindera obtusiloba extract suppresses growth and attenuates insulin like growth factor-1 receptor signaling and NF-kappaB activity in human liver cancer cell lines. BMC Complementary and Alternative Medicine. 2011;11:39. https://doi.org/10.1186/1472-6882-11-39

72. Yam MF, Ang LF, Lim CP, Ameer OZ, Salman IM, Ahmad $\mathrm{M}$, et al. Antioxidant and hepatoprotective effects of Murdannia bracteata methanol extract. Journal of Acupuncture and Meridian Studies. 2010;3(3):197-202. https://doi.org/10.1016/S2005-2901(10)60036-2

73. $\mathrm{Xu} \mathrm{R}$, Ye $\mathrm{H}$, Sun $\mathrm{Y}, \mathrm{Tu} \mathrm{Y}$, Zeng $\mathrm{X}$. Preparation, preliminary characterization, antioxidant, hepatoprotective and antitumor activities of polysaccharides from the flower of tea plant (Camellia sinensis). Food and Chemical Toxicology. 2012;50(7):2473-80.

https://doi.org/10.1016/j.fct.2011.10.047

74. Niu C, Sheng Y, Yang R, Lu B, Bai Q, Ji L, et al. Scutellarin protects against the liver injury induced by diosbulbin $\mathrm{B}$ in mice and its mechanism. Journal of Ethnopharmacology. https://doi.org/10.1016/j.jep.2015.02.031

75. Lv L, Zheng L, Dong D, Xu L, Yin L, Xu Y, et al. Dioscin, a natural steroid saponin, induces apoptosis and DNA damage through reactive oxygen species: a potential new drug for treatment of glioblastoma multiforme. Food and Chemical Toxicology. 2013;59:657-69. https://doi.org/10.1016/j.fct.2013.07.012

76. Zhu J, Viñas R, Smith EE. In vitro evaluation of human liver cancer cells and the potential cytotoxicity of Tecoma stans (Bignoniaceae) and Brickellia cavanillesi (Asteraceae) both single and in combination. Toxicological and Environmental Chemistry. 2008;90(4):801-8. https://doi.org/10.1080/02772240701740387

77. Wang ZY, Kang H, Ji LL, Yang YQ, Liu TY, Cao ZW, et al. Proteomic characterization of the possible molecular targets of pyrrolizidine alkaloid isoline-induced hepatotoxicity. Environmental Toxicology and Pharmacology. https://doi.org/10.1016/j.etap.2012.06.013

78. Niu C, Wang J, Ji L, Wang Z. Protection of Angelica sinensis (Oliv) diels against hepatotoxicity induced by Dioscorea bulbifera L. And its mechanism. BioScience Trends. 2014;8(5):253-9 https://doi.org/10.5582/bst.2014.01076

79. Bishayee A, Darvesh AS, Politis T, McGory R. Resveratrol and liver disease: from bench to bedside and community. Liver International. 2010;30(8):1103-14. https://doi.org/10.1111/j.1478-3231.2010.02295.x
80. Baradaran A, Nasri H, Rafieian-Kopaei M. Comment on: anti-oxidative stress activity of stachys lavandulifolia aqueous extract in humans. Cell Journal. 2013;15(3):2723.

81. Murakami A. Dose-dependent functionality and toxicity of green tea polyphenols in experimental rodents. Archives of Biochemistry and Biophysics. 2014;557:3-10. https://doi.org/10.1016/j.abb.2014.04.018

82. Stiborova M, Hajek M, Frei E, Schmeiser HH. Carcinogenic and nephrotoxic alkaloids aristolochic acids upon activation by NADPH: cytochrome P450 reductase form adducts found in DNA of patients with Chinese herbs nephropathy. General Physiology and Biophysics. 2001; 20(4):375-92.

83. Patel SS, Beer S, Kearney DL, Phillips G, Carter BA. Green tea extract: a potential cause of acute liver failure. World Journal of Gastroenterology. 2013;19(31):5174-7. https://doi.org/10.3748/wjg.v19.i31.5174

84. Wang Y, Deng L, Wang Y, Zhong H, Jiang X, Chen J. Natural plant extract tubeimoside I induces cytotoxicity via the mitochondrial pathway in human normal liver cells. Molecular Medicine Reports. 2011;4(4):713-8.

85. Chang HL, Hsu HK, Su JH, Wang PH, Chung YF, Chia YC, et al. The fractionated Toona sinensis leaf extract induces apoptosis of human ovarian cancer cells and inhibits tumor growth in a murine xenograft model. Gynecologic Oncology. 2006;102(2):309-14 https://doi.org/10.1016/j.ygyno.2005.12.023

86. Lawenda BD, Kelly KM, Ladas EJ, Sagar SM, Vickers A, Blumberg JB. Should supplemental antioxidant administration be avoided during chemotherapy and radiation therapy? Journal of the National Cancer Institute. 2008;100(11):773-83 https://doi.org/10.1093/jnci/djn148

87. Mut-Salud N, Álvarez PJ, Garrido JM, Carrasco E, Aránega A, Rodríguez-Serrano F. Antioxidant intake and antitumor therapy: toward nutritional recommendations for optimal results. Oxidative Medicine and Cellular Longevity. 2016; 2016:6719534. https://doi.org/10.1155/2016/6719534

88. Yap KY, See CS, Chan A. Clinically-relevant chemotherapy interactions with complementary and alternative medicines in patients with cancer. Recent Patents on Food, Nutrition \& Agriculture. 2010;2(1):12-55. https://doi.org/10.2174/2212798411002010012

89. Efferth T, Schottler U, Krishna S, Schmiedek P, Wenz F, Giordano FA. Hepatotoxicity by combination treatment of temozolomide, artesunate and Chinese herbs in a glioblastoma multiforme patient: case report review of the literature. Archives of Toxicology. 2017;91(4):183346. https://doi.org/10.1007/s00204-016-1810-z 